\title{
Data report: microanalytical and geothermometric investigations on granoblastic dikes from the gabbro-dike transition from Hole 1256D (IODP Expedition 335, East Pacific Rise) ${ }^{1}$
}

\author{
Jürgen Koepke ${ }^{2}$ and Niko Goetze ${ }^{2}$
}

\section{Chapter contents}

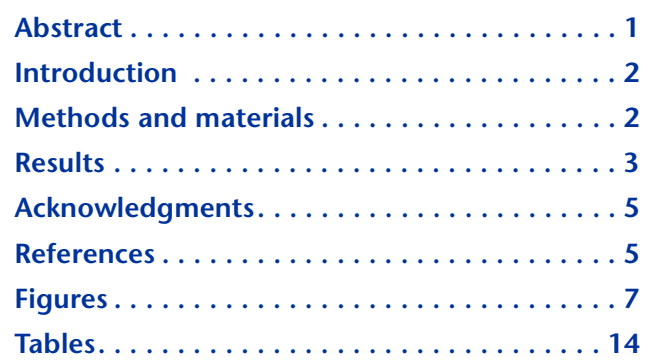

${ }^{1}$ Koepke, J., and Goetze, N., 2015. Data report: microanalytical and geothermometric investigations on granoblastic dikes from the gabbro-dike transition from Hole 1256D (IODP Expedition 335, East Pacific Rise). In Teagle, D.A.H., Ildefonse, B., Blum, P., and the Expedition 335 Scientists, Proc. IODP, 335: Tokyo (Integrated Ocean Drilling Program Management International, Inc.).

doi:10.2204/iodp.proc.335.201.2015

${ }^{2}$ Institut für Mineralogie, Leibniz Universitaet

Hannover, Callinstrasse 3, 30167 Hannover, Germany. Correspondence author: koepke@mineralogie.uni-hannover.de

\section{Abstract}

In this data report we present detailed microanalytical results obtained with electron microprobe on 6 granoblastic dikes recovered during Integrated Ocean Discovery Program Expedition 335 from the gabbro-dike transition in Hole 1256D (Eastern Equatorial Pacific). The data set includes 79 compositions of plagioclases, clinopyroxenes, orthopyroxenes, amphiboles, and Fe-Ti oxides based on 1150 single analyses.

All samples except one display phenocrysts of plagioclase in a granoblastic matrix equilibrated in the pyroxene hornfels facies. The analytical results reveal that the plagioclase phenocrysts are much higher in anorthite component than those of the granoblastic matrix, with compositions typical of plagioclases from fresh pillow basalts and dikes from the upper part of the drill core, implying that these phenocrysts correspond to relics inherited from the primary magmatic stage.

Four samples display domains where clinopyroxene and orthopyroxene are arranged in vein- or bandlike structures, or in coarser grained monomineralic clusters. Clinopyroxenes and orthopyroxene from these domains show compositions overlapping widely with those of the matrix pyroxenes. This supports the hypothesis that these domains are derived from precursor structures generated by pervasive hydrothermal alteration, like hydrothermal veins and patches in the basalts. They were subsequently transformed by the contact metamorphic overprint into parageneses typical for the pyroxene hornfels facies, showing textural domains like bands and clusters inherited from the hydrothermal alteration stage, but with mineral compositions identical to those of the granoblastic matrix.

Two-pyroxene geothermometry reveals equilibrium temperatures for the peak metamorphism of the granoblastic overprint ranging from $930^{\circ} \mathrm{C}$ to $990^{\circ} \mathrm{C}$, characteristic of an equilibration within the pyroxene hornfels facies. The estimated temperatures are very similar to equilibrium temperatures estimated by the same method for granoblastic dikes drilled during Expedition 312. These temperatures, together with the geological setting of the granoblastic dikes within the gabbro-dike transition in fastspread crust, imply that the granoblastic hornfels can be regarded as preserved fragments of a conductive thermal boundary layer. 


\section{Introduction}

Oceanic crust formed at fast-spreading rates exhibits relatively uniform seismic stratigraphy (e.g., Canales et al., 2003) and is regarded as layered and relatively homogeneous. This contrasts with the oceanic crust generated at slow-spreading ridges that is characterized by considerable heterogeneity, and where crustal accretion is partly controlled by tectonic rather than solely by magmatic processes (e.g., Cannat et al., 1995; Dick et al., 2008). In spite of the global importance of fast-spreading oceanic crust, up to now only one penetration of intact fast-spreading oceanic crust from the pillow basalts down to the plutonic layer exists: it was established by the IODP (Integrated Ocean Drilling Program) multiexpedition mission "Superfast Crust" at Site 1256. It is located in the eastern equatorial Pacific on 15 Ma oceanic crust of the Cocos plate formed at the East Pacific Rise (EPR) under superfast spreading conditions (220 $\mathrm{mm} / \mathrm{y}$, full spreading rate; Wilson, 1996). Hole 1256D, initiated during Ocean Drilling Program (ODP) Leg 206 and continued during IODP Expeditions 309, 312, and 335, penetrated the entire upper oceanic crust, passing through a $\sim 250 \mathrm{~m}$ thick sediment sequence, a $\sim 800 \mathrm{~m}$ thick lava series, and a relatively thin $\sim 350 \mathrm{~m}$ thick sheeted dike complex before finally extending $\sim 100 \mathrm{~m}$ into the uppermost gabbros, which consist of two apparently intrusive bodies (e.g., Teagle, Alt, Umino, Miyashita, Banerjee, Wilson, and the Expedition 309/312 Scientists, 2006; Teagle, Ildefonse, Blum, and the Expedition 335 Scientists, 2012). Hole 1256D penetrated for the first time the sheeted dike rooting zone, thus representing our only reference section for the important dike-gabbro transition of typical fast-spreading oceanic crust. This transition is a very complex zone, where magmatic, metamorphic, and hydrothermal processes all occur in close proximity: below, the axial melt lens (AML; e.g., Detrick et al., 1987) filled with a basaltic magma at a temperature of $\sim 1200^{\circ} \mathrm{C}$, and above, the seawater hydrothermal cells operate at temperatures of $\sim 400^{\circ} \mathrm{C}$ (based on the measured exit temperatures at EPR vents; e.g., Von Damm et al., 2003). Theoretical models predict that the heat of the AML is exchanged across a thin $(<100 \mathrm{~m})$, hot $\left(>650^{\circ} \mathrm{C}\right)$, impermeable conductive boundary layer (CBL) sandwiched between the AML and the sheeted dikes (e.g., Lister, 1974).

Thanks to IODP Expeditions 312 and 335, now the first in situ samples from such a CBL zone are available: a $\sim 70 \mathrm{~m}$ thick zone of "granoblastic dikes," representing high-grade metamorphosed, previously hydrothermally altered basalts of the sheeted dike complex, in which gabbros were intruded, showing a marked heterogeneity in lithofacies. These gabbros are interpreted as frozen remnants of a deeper AML, not yet reached by drilling (e.g., France et al., 2009; Koepke et al., 2011). The recovered samples document a wide spectrum of magmatic/metamorphic rocks ranging from basaltic to evolved compositions and the intimate coupling between temporally and spatially intercalated magmatic, hydrothermal and (prograde and retrograde) metamorphic processes. Here we present detailed microanalytical results obtained with electron microprobe on six granoblastic dike samples recovered during Expedition 335. Four of them are identical to samples from which shipboard thin sections were prepared (Table T1), which are petrographically characterized in Teagle, Ildefonse, Blum, and the Expedition 335 Scientists (2012). Special focus of this investigation was to estimate the temperature of the granoblastic overprint by applying geothermometers based on pyroxene and amphibole compositions and to characterize the composition of plagioclase phenocrysts observed in the granoblastic dikes and interpreted as relics from the primary magmatic stage that survived the granoblastic overprint (Teagle, Ildefonse, Blum, and the Expedition 335 Scientists, 2012). Detailed reports on the geology and characterization of Site 1256 including maps are given in Teagle, Alt, Umino, Miyashita, Banerjee, Wilson, and the Expedition 309/312 Scientists (2006) and Teagle, Ildefonse, Blum, and the Expedition 335 Scientists (2012).

\section{Methods and materials}

\section{Electron microprobe analysis}

Major element concentrations of minerals were determined using a Cameca SX100 equipped with five spectrometers and the operating software "Peak Sight" at the Institut für Mineralogie (University of Hannover, Germany). All data were obtained using a $15 \mathrm{kV}$ acceleration potential, $\mathrm{K} \alpha$ or $\mathrm{K} \beta$ emission for all elements, and the matrix correction "PAP" according to Pouchou and Pichoir (1991). Calibration material includes natural wollastonite ( $\mathrm{Si}$ and $\mathrm{Ca}$ ), albite $(\mathrm{Na})$, orthoclase $(\mathrm{K})$, halite $(\mathrm{Cl})$, strontium fluoride (F), and synthetic $\mathrm{Al}_{2} \mathrm{O}_{3}, \mathrm{Fe}_{2} \mathrm{O}_{3}, \mathrm{MgO}, \mathrm{TiO}_{2}$, $\mathrm{Mn}_{3} \mathrm{O}_{4}, \mathrm{~V}_{2} \mathrm{O}_{3}$, and $\mathrm{Cr}_{2} \mathrm{O}_{3}$. Thallium acid phthalate (TAP) single crystal was used as the diffracting crystal for $\mathrm{Na}, \mathrm{Mg}, \mathrm{Si}, \mathrm{Al}$, and $\mathrm{F}$; pentanerythritol (PET) single crystal for $\mathrm{Ca}, \mathrm{Cr}, \mathrm{K}, \mathrm{Ti}, \mathrm{V}$, and $\mathrm{Cl}$; and lithium fluoride (LIF) single crystal for Fe and Mn. Most of the data were obtained using a $15 \mathrm{nA}$ beam current and static (focused) beam. Counting times were $10 \mathrm{~s}$ for major elements, $40 \mathrm{~s}$ for $\mathrm{Ca}$ in olivine, $30 \mathrm{~s}$ for $\mathrm{Cr}$ in pyroxenes, and $60 \mathrm{~s}$ for $\mathrm{F}$ and $\mathrm{Cl}$ in hydrous minerals. Core and rim analyses were obtained using a focused beam. 


\section{Samples}

Microanalytical data were collected from six thin sections of granoblastic dikes recovered during Expedition 335 in Hole 1256D, covering 1507-1521 meters below seafloor (mbsf). The samples were drilled in situ (one sample) or collected from reverse circulation junk baskets (RCJB; 4 samples) and from external junk baskets (EXJB; one sample). An overview of sample information is presented in Table T1. Further details about the samples and about the hole cleaning tools, including the junk baskets, can be found in Teagle, Ildefonse, Blum, and the Expedition 335 Scientists (2012).

\section{Results}

\section{Petrographic results}

Petrographic details of the samples are shown in Table T2. They represent granoblastic hornfels with a groundmass composed of microgranular plagioclase, clinopyroxene, orthopyroxene, and Fe-Ti oxides. In some samples, secondary amphibole was identified, always in small amounts ( $<5 \mathrm{vol} \%)$. The goal of this study was to characterize the compositions of those minerals in typical granoblastic dikes, showing specific petrographic features observed on board during Expedition 335 (Teagle, Ildefonse, Blum, and the Expedition 335 Scientists, 2012):

1. All samples except one (Sample 335-U1256DRun12-RCJB-Q) contain phenocrysts of plagioclase integrated into the granoblastic matrix (Figs. F1, F2, F3, F4). These structures were previously interpreted as relict phenocrysts from the primary magmatic stage that survived the granoblastic overprint (Teagle, Ildefonse, Blum, and the Expedition 335 Scientists, 2012).

2. Two samples (Run12-RCJB-B and Run15-EXJB) contain plagioclases that display very patchy zoning as a result of the presence of dusty ghost cores (Fig. F5).

3. Four samples (Run12-RCJB-B, Run12-RCJB-Q, Run12-RCJB-S, and Run15-EXJB) display domains where clinopyroxene and orthopyroxene are arranged in vein- or bandlike structures or in monomineralic clusters with much larger grain size than the granoblastic matrix (Fig. F6). Some of these samples are foliated, whereas the majority of the samples are not.

\section{Microanalytical results}

Compositions of the analyzed phases (plagioclase, clinopyroxene, orthopyroxene, amphibole, and Fe-Ti oxides) in the investigated granoblastic dikes are shown in Table T3. To obtain a general overview of the mineral compositions, several measurements were collected from all minerals present in individual granoblastic dikes. Whenever possible, individual phases were analyzed in core and rim areas to detect zonation. If an individual sample contained specific domains like veins, bands, or clusters, analyses of these domains were obtained separately and listed in Table T3. In the following, we focus on those features highlighted in the previous section.

\section{Plagioclase \\ Composition of matrix and phenocrysts}

The cores of matrix plagioclases show anorthite (An) contents varying in a small interval between 50.1 and $54.7 \mathrm{~mol} \%$ (Fig. F7). Only one sample, 3351256D-235R-1W-19, contains matrix plagioclase with core compositions significantly higher in An (68.5 mol\%; Table T3), due to relics of primary Anrich plagioclase. Rim compositions are very similar to those of the cores, varying between 47.5 and 56.4 $\mathrm{mol} \%$, and confirming the petrographic result that most granoblastic dikes bear matrix plagioclases without significant zoning. Only a few samples contain matrix plagioclases with characteristic patchy zoning due to the presence of ghost cores (see below). In general, the compositions of the matrix plagioclase overlap with those from granoblastic dikes recovered during Expedition 312 (Koepke et al., 2008) (Fig. F7).

In contrast to the matrix plagioclases, the plagioclase phenocrysts have much higher An contents between 65.5 and $72.7 \mathrm{~mol} \%$ (core analyses). They show compositions typical of plagioclases from the fresh pillow basalts and dikes from the upper part of Hole 1256D (Fig. F7; data from Dziony et al., 2008), implying that these phenocrysts correspond to relics inherited from the primary magmatic stage. The inherited magmatic cores can be clearly identified in backscattered electron (BSE) images by their euhedral shapes showing zoning with very a sharp boundary against the granoblastic matrix (Figs. F1, F2, F3, F4). To determine the variation in An content throughout the phenocryst zonation, analytic profiles were measured through the phenocrysts including the adjacent matrix for four samples. The results are presented in Figures F1, F2, F3, and F4. By obtaining very accurate $\mathrm{CaAl}-\mathrm{NaSi}$ concentration profiles at the rims of such phenocrysts, Zhang et al. (2014) applied diffusion modeling techniques and extracted cooling rates for the magma chamber roof rocks at Site 1256. Their results show that cooling from the peak thermal overprint at $1000^{\circ} \mathrm{C}-1050^{\circ} \mathrm{C}$ to $600^{\circ} \mathrm{C}$ are yielded within $\sim 10-30 \mathrm{y}$ as a result of very effective hydrothermal circulation above the melt lens during a phase of magma starvation. 


\section{Composition of the ghost cores}

Matrix plagioclases with typical patchy zoning were analyzed in two samples (Table T3). The BSE images reveal the presence of cores enriched in An content with a sharp boundary against an interstitial network composed of plagioclase lower in An (Fig. F5). The dusty appearance of these cores is due to millions of micrometer-sized oxide inclusions. A microprobe profile of An content through a typical core is also shown in Figure F5. The plagioclase cores show An contents varying between 49.4 and $53.9 \mathrm{~mol} \%$, corresponding to the composition of matrix plagioclases in granoblastic dikes (see above). The composition of the interstitial network is strongly enriched in albite component ( $30 \mathrm{~mol} \%$ on average), implying that these compositions are due to a secondary hydrothermal overprint at lower temperatures. This hypothesis is supported by a relatively high amount of secondary amphibole in one sample (335-U1256D-Run12-RCJB-B).

\section{Pyroxenes}

\section{Composition of matrix and bands/clusters}

Clinopyroxenes of the granoblastic matrix show relatively low $\mathrm{TiO}_{2}$ and $\mathrm{Al}_{2} \mathrm{O}_{3}$ contents (0.3-0.6 and 0.8-1.4 wt $\%$ for core analyses, respectively) and correspond to compositions typical of granoblastic dikes recovered during Expedition 312 (Fig. F7). They strongly contrast with compositions from the primary magmatic stage analyzed in fresh lavas and dike of Hole $1256 \mathrm{D}$, which show high $\mathrm{Al}_{2} \mathrm{O}_{3}$ contents (Fig. F7; data from Dziony et al., 2008), and also high $\mathrm{Cr}_{2} \mathrm{O}_{3}$ contents, whereas the $\mathrm{Cr}_{2} \mathrm{O}_{3}$ concentrations in clinopyroxenes from the granoblastic dikes are always below the detection limit. All analyzed orthopyroxenes vary only over a small range, with relatively low $\mathrm{TiO}_{2}$ and $\mathrm{Al}_{2} \mathrm{O}_{3}$ contents (0.2-0.4 and $0.6-0.9 \mathrm{wt} \%$, respectively) that are very similar to orthopyroxenes analyzed in granoblastic dikes recovered during Expedition 312 (Fig. F7).

Clinopyroxenes and orthopyroxenes analyzed in special domains like veins, bands, and clusters (Fig. F6), or as inclusions in other minerals, show compositions overlapping widely with those of the matrix pyroxenes (Fig. F7), implying that a high degree of chemical equilibrium has been achieved in these samples during the metamorphism. This supports the hypothesis, based on microscopic observation, that these special domains are derived from precursor structures generated by pervasive hydrothermal alteration, such as hydrothermal veins and patches in the basalts. These were subsequently transformed by the contact metamorphic overprint into the gra- noblastic paragenesis, occurring as textural domains such as bands and clusters, but with mineral compositions identical to the granoblastic matrix, as a consequence of achieving a global chemical equilibrium in these rocks.

\section{Amphiboles}

All analyzed amphiboles show compositions with $\mathrm{Na}$ $+\mathrm{K}$ on A position below 0.5 corresponding to magnesiohornblendes and actinolites, which is typical for an equilibration within the amphibolite facies. Thus, the conditions of formation do not correspond to those of the peak metamorphism in the pyroxene hornfels facies (see below), implying that the amphiboles were formed during a later hydrothermal overprint after the high-temperature metamorphism. This in agreement with the observation that most of the amphiboles correspond to overgrowth or late veins, and that the amphibole-bearing samples show a relatively high amount of secondary, albite-rich plagioclases, as well as coexisting titanite.

\section{Geothermometry}

To calculate equilibrium temperatures, two different geothermometry techniques were used. We applied the two-pyroxene geothermometer using QUILF (Andersen et al., 1993) and equation 36 of Putirka (2008), as well as the semiquantitative Ti-in-amphibole geothermometer of Ernst and Liu (1998). The application of the latter is possible due to the general presence of a Ti phase coexisting with the amphibole (mostly Fe-Ti oxide and/or titanite).

The results of these calculations are presented in Table T4. Both two-pyroxene geothermometers revealed nearly identical results in the six samples for the peak metamorphism equilibrium temperatures of the granoblastic overprint, varying only within a relatively small temperature range of $930^{\circ} \mathrm{C}-990^{\circ} \mathrm{C}$ for QUILF and $930^{\circ} \mathrm{C}-980^{\circ} \mathrm{C}$ for the Putirka (2008) method. These temperatures are characteristic of the pyroxene hornfels metamorphic facies, and are very similar to equilibrium temperatures estimated by QUILF for the granoblastic dikes recovered during Expedition 312 ranging from $930^{\circ} \mathrm{C}$ to $1050^{\circ} \mathrm{C}$ (Koepke et al., 2008). These temperatures, together with the specific geological setting of these rocks within the gabbro-dike transition of fast-spreading crust, imply that the granoblastic hornfels can be regarded as preserved fragments of the CBL.

Alt et al. (2010) presented slightly lower equilibrium temperatures in granoblastic dikes recovered during Expedition 312 , ranging from $800^{\circ} \mathrm{C}$ to $920^{\circ} \mathrm{C}$. However, they used the Brey and Köhler (1990) geother- 
mometer, which results in systematically lower temperatures compared to the QUILF two-pyroxene thermometer (see discussion in Alt et al., 2010). Our estimated temperature range is also in agreement with temperature estimations for hornfels from the gabbro-dike transitions for the EPR crust at Pito and Hess Deeps and in the Oman and Troodos ophiolites, where estimated peak temperatures vary from $700^{\circ} \mathrm{C}$ to $1000^{\circ} \mathrm{C}$ (Gillis, 2008).

Distinctly lower equilibrium temperatures were derived from the Ti-in-amphibole geothermometer of Ernst and Liu (1998), ranging between $510^{\circ} \mathrm{C}$ and $630^{\circ} \mathrm{C}$ for hornblende and actinolite veins or overgrowth within the granoblastic dike. We interpret this as the record of a secondary metamorphic overprint under hydrous conditions in the amphibolite facies, probably related to hydrothermal alteration caused by seawater ingress. One hornblende forming blebs in orthopyroxene in Sample 335-U1256DRun12-RCJB-Q revealed a distinctly higher equilibrium temperature of $853^{\circ} \mathrm{C}$ (Table T4). We attribute this temperature to a retrograde cooling stage under hydrous conditions within the hornblende hornfels facies.

\section{Acknowledgments}

This study used samples provided by the Integrated Ocean Drilling Program. The Project was funded by the Deutsch Forschungsgemeinschaft (DFG; Project KO 1723/12-1,2).

\section{References}

Andersen, D.J., Lindsley, D.H., and Davidson, P.M., 1993. QUILF: a Pascal program to assess equilibria among $\mathrm{Fe}-$ Mg-Mn-Ti oxides, pyroxenes, olivine, and quartz. Comp. Geosci., 19(9):1333-1350. doi:10.1016/00983004(93)90033-2

Alt, J.C., Laverne, C., Coggon, R.M., Teagle, D.A.H., Banerjee, N.R., Morgan, S., Smith-Duque, C.E., Harris, M., and Galli, L., 2010. Subsurface structure of a submarine hydrothermal system in ocean crust formed at the East Pacific Rise, ODP/IODP Site 1256. Geochem., Geophys., Geosyst., 11(10):Q10010. doi:10.1029/2010GC003144

Brey, G.P., and Köhler, T., 1990. Geothermobarometry in four-phase lherzolites, II. New thermobarometers, and practical assessment of existing thermobarometers. $J$. Petrol., 31(6):1353-1378. doi:10.1093/petrology/ 31.6.1353

Canales, J.P., Detrick, R.S., Toomey, D.R., and Wilcock, W.S.D., 2003. Segment-scale variations in the crustal structure of 150-300 kyr old fast spreading oceanic crust (East Pacific Rise, $8^{\circ} 15^{\prime} \mathrm{N}-10^{\circ} 5^{\prime} \mathrm{N}$ ) from wide-angle seis- mic refraction profiles. Geophys. J. Int., 152(3):766-794. doi:10.1046/j.1365-246X.2003.01885.X

Cannat, M., Mével, C., Maia, M., Deplus, C., Durand, C. Gente, P., Agrinier, P., Belarouchi, A., Dubuisson, G., Humler, E., and Reynolds, J., 1995. Thin crust, ultramafic exposures, and rugged faulting patterns at the Mid-Atlantic Ridge $\left(22^{\circ}-24^{\circ} \mathrm{N}\right)$. Geology, 23(1):49-52. doi:10.1130/0091-

7613(1995)023<0049:TCUEAR>2.3.CO;2

Detrick, R.S., Buhl, P., Vera, E., Mutter, J., Orcutt, J., Madsen, J., and Brocher, T., 1987. Multi-channel seismic imaging of a crustal magma chamber along the East Pacific Rise. Nature, 326(6108):35-41. doi:10.1038/ 326035a0

Dick, H.J.B., Tivey, M.A., and Tucholke, B.E., 2008. Plutonic foundation of a slow-spreading ridge segment: oceanic core complex at Kane Megamullion, $23^{\circ} 30^{\prime} \mathrm{N}$, $45^{\circ} 20^{\prime}$ W. Geochem., Geophys., Geosyst., 9(5). doi:10.1029/2007GC001645

Dziony, W., Koepke, J., and Holtz, F., 2008. Data report: petrography and phase analyses in lavas and dikes from Hole 1256D (ODP Leg 206 and IODP Expedition 309, East Pacific Rise). In Teagle, D.A.H., Alt, J.C., Umino, S., Miyashita, S., Banerjee, N.R., Wilson, D.S., and the Expedition 309/312 Scientists, Proc. IODP, 309/312: College Station, TX (Integrated Ocean Drilling Program Management International, Inc.). doi:10.2204/ iodp.proc.309312.201.2008

Ernst, W.G., and Liu, J., 1998. Experimental phase-equilibrium study of Al- and Ti-contents of calcic amphibole in MORB:a semiquantitative thermobarometer. Am. Mineral., 83(9-10):952-969. http://ammin.geoscienceworld.org/content/83/9-10/952.extract

France, L., Ildefonse, B., and Koepke, J., 2009. Interactions between magma and the hydrothermal system in the Oman ophiolite and in IODP Hole 1256D: fossilisation of dynamic melt lens at fast spreading ridges. Geochem., Geophys., Geosyst., 10(10):Q10O19. doi:10.1029/ 2009GC002652

Gillis, K.M., 2008. The roof of an axial magma chamber: a hornfelsic heat exchanger. Geology, 36(4):299-302. doi:10.1130/G24590A.1

Koepke, J., Christie, D.M., Dziony, W., Holtz, F., Lattard, D., Maclennan, J., Park, S., Scheibner, B., Yamasaki, T., and Yamazaki, S., 2008. Petrography of the dike-gabbro transition at IODP Site 1256 (equatorial Pacific): the evolution of the granoblastic dikes. Geochem., Geophys., Geosyst., 9(7):Q07O09. doi:10.1029/2008GC001939

Koepke, J., France, L., Müller, T., Faure, F., Goetze, N., Dziony, W., and Ildefonse, B., 2011. Gabbros from IODP Site 1256, equatorial Pacific: insight into axial magma chamber processes at fast spreading ocean ridges. Geochem., Geophys., Geosyst., 12(9):Q09014. doi:10.1029/ 2011GC003655

Pouchou, J.-L., and Pichoir, F., 1991. Quantitative analysis of homogeneous or stratified microvolumes applying the model "PAP." In Heinrich, K.F.J., and Newbury, D.E. 
(Eds.), Electron Probe Quantification: New York (Plenum Press), 31-75. doi:10.1007/978-1-4899-2617-3_4

Putirka, K.D., 2008. Thermometers and barometers for volcanic systems. Rev. Mineral. Geochem., 69(1):61-120. doi:10.2138/rmg.2008.69.3

Teagle, D.A.H., Alt, J.C., Umino, S., Miyashita, S., Banerjee, N.R., Wilson, D.S., and the Expedition 309/312 Scientists, 2006. Proc. IODP, 309/312: Washington, DC (Integrated Ocean Drilling Program Management International, Inc.). doi:10.2204/ iodp.proc.309312.2006

Teagle, D.A.H., Ildefonse, B., Blum, P., and the Expedition 335 Scientists, 2012. Proc. IODP, 335: Tokyo (Integrated Ocean Drilling Program Management International, Inc.). doi:10.2204/iodp.proc.335.2012

Von Damm, K.L., Lilley, M.D., Shanks, W.C., III, Brockington, M., Bray, A.M., O’Grady, K.M., Olson, E., Graham,
A., Proskurowski, G., and the SouEPR Science Party, 2003. Extraordinary phase separation and segregation in vent fluids from the southern East Pacific Rise. Earth Planet. Sci. Lett., 206(3-4):365-378. doi:10.1016/S0012821X(02)01081-6

Wilson, D.S., 1996. Fastest known spreading on the Miocene Cocos-Pacific plate boundary. Geophys. Res. Lett., 23(21):3003-3006. doi:10.1029/96GL02893

Zhang, C., Koepke, J., Kirchner, C., Götze, N., and Behrens, H., 2014. Rapid hydrothermal cooling above the axial melt lens at fast-spreading mid-ocean ridge. Sci. Rep., 4:6342. doi:10.1038/srep06342

Initial receipt: 31 May 2014

Acceptance: 20 November 2014

Publication: 24 March 2015

MS 335-201 
Figure F1. Back-scattered electron (BSE) image of relict plagioclase phenocrysts and related electron microprobe profile for anorthite (An) content in a granoblastic hornfels recovered during Expedition 335 (Sample 3351256D-235R-1W-19). Yellow line $=$ position of profile. $\mathrm{Pl}=$ plagioclase, $\mathrm{Cpx}=$ clinopyroxene, $\mathrm{Opx}=$ orthopyroxene, $\mathrm{Ox}=$ oxide.
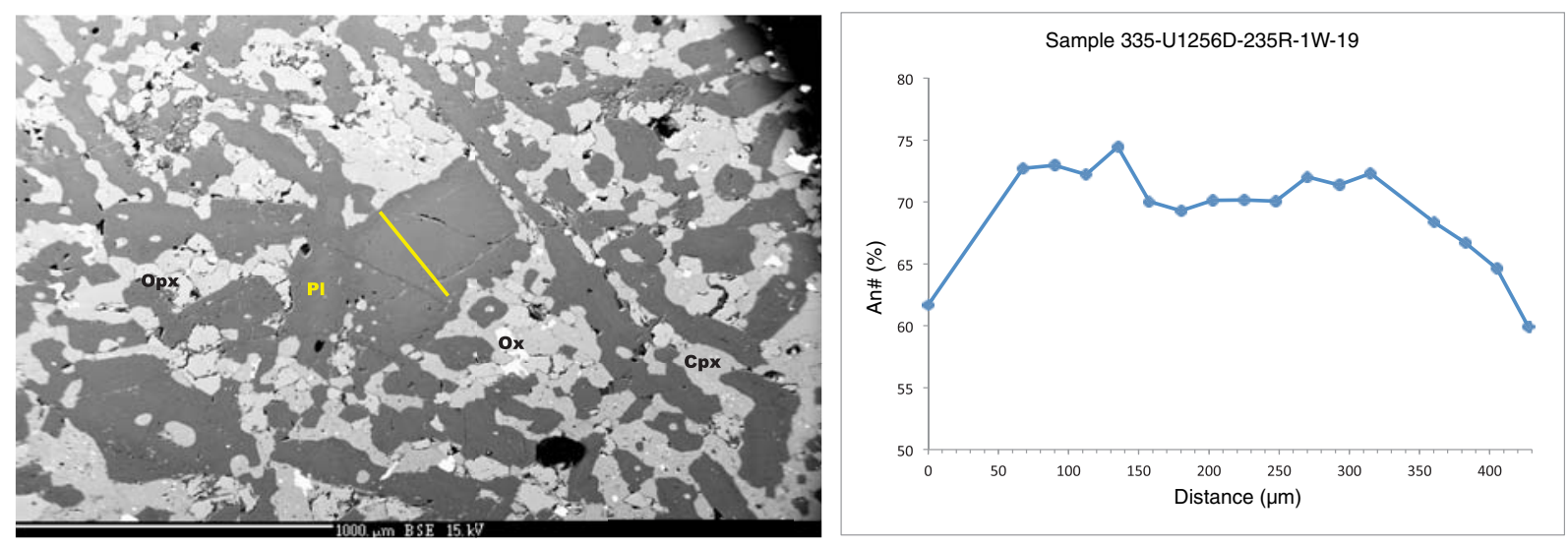
Figure F2. Backscattered electron (BSE) images of three relict plagioclase phenocrysts and related electron microprobe profiles for anorthite (An) content in a granoblastic hornfels recovered during Expedition 335 (Sample 335-U1256D-Run12-RCJB-S). Yellow lines = position of profiles. $\mathrm{Pl}=$ plagioclase, $\mathrm{Cpx}=$ clinopyroxene, Opx = orthopyroxene, $\mathrm{Ox}=$ oxide.
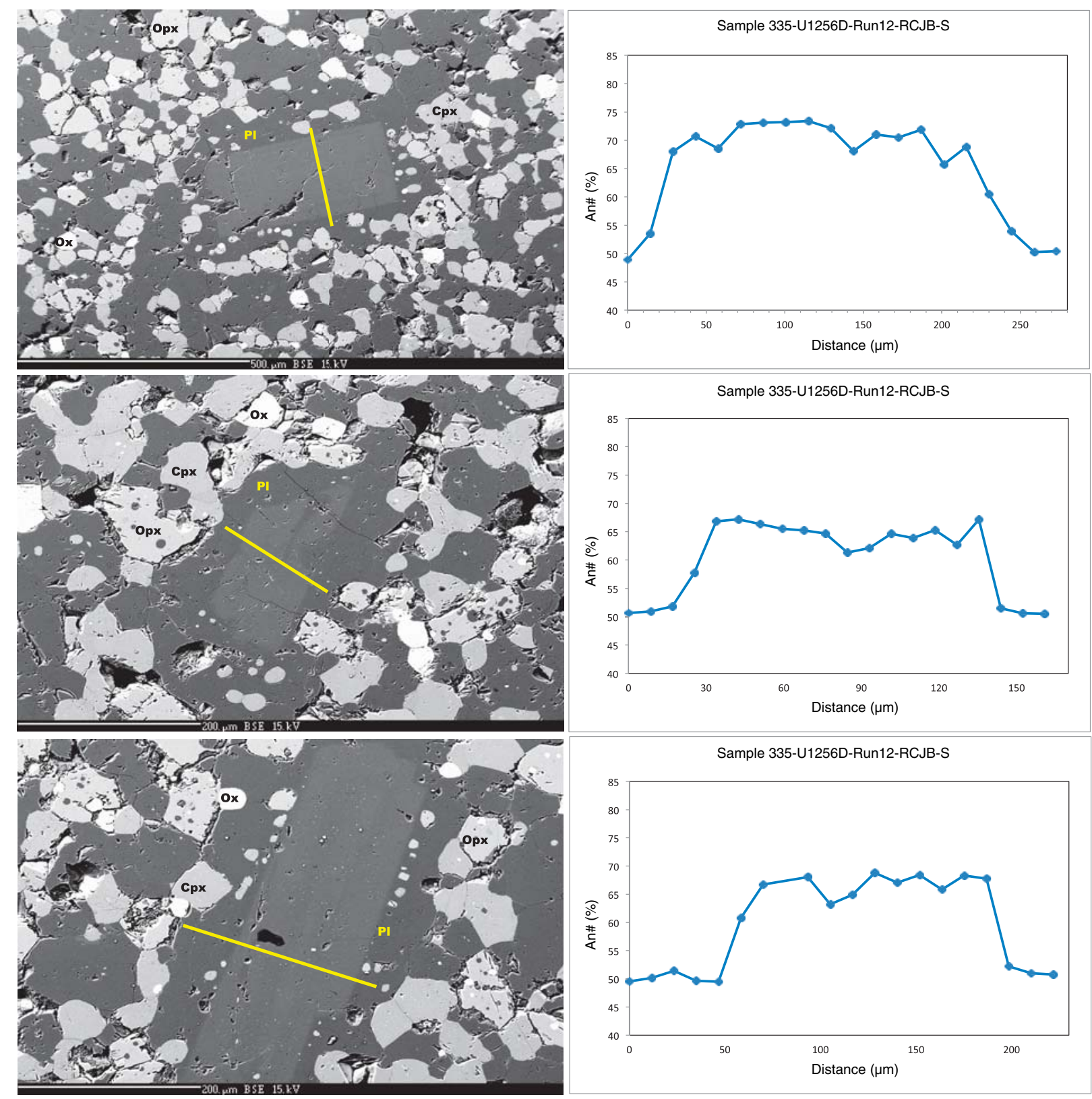
Figure F3. Backscattered electron (BSE) images of two relict plagioclase phenocrysts and related electron microprobe profiles for anorthite $(\mathrm{An})$ content in a granoblastic hornfels recovered during Expedition 335 (Sample 335-U1256D-Run15-EXJB). Yellow lines $=$ position of profiles. $\mathrm{Pl}=$ plagioclase, $\mathrm{Cpx}=$ clinopyroxene, $\mathrm{Opx}=\mathrm{or}-$ thopyroxene, $\mathrm{Ox}=$ oxide.
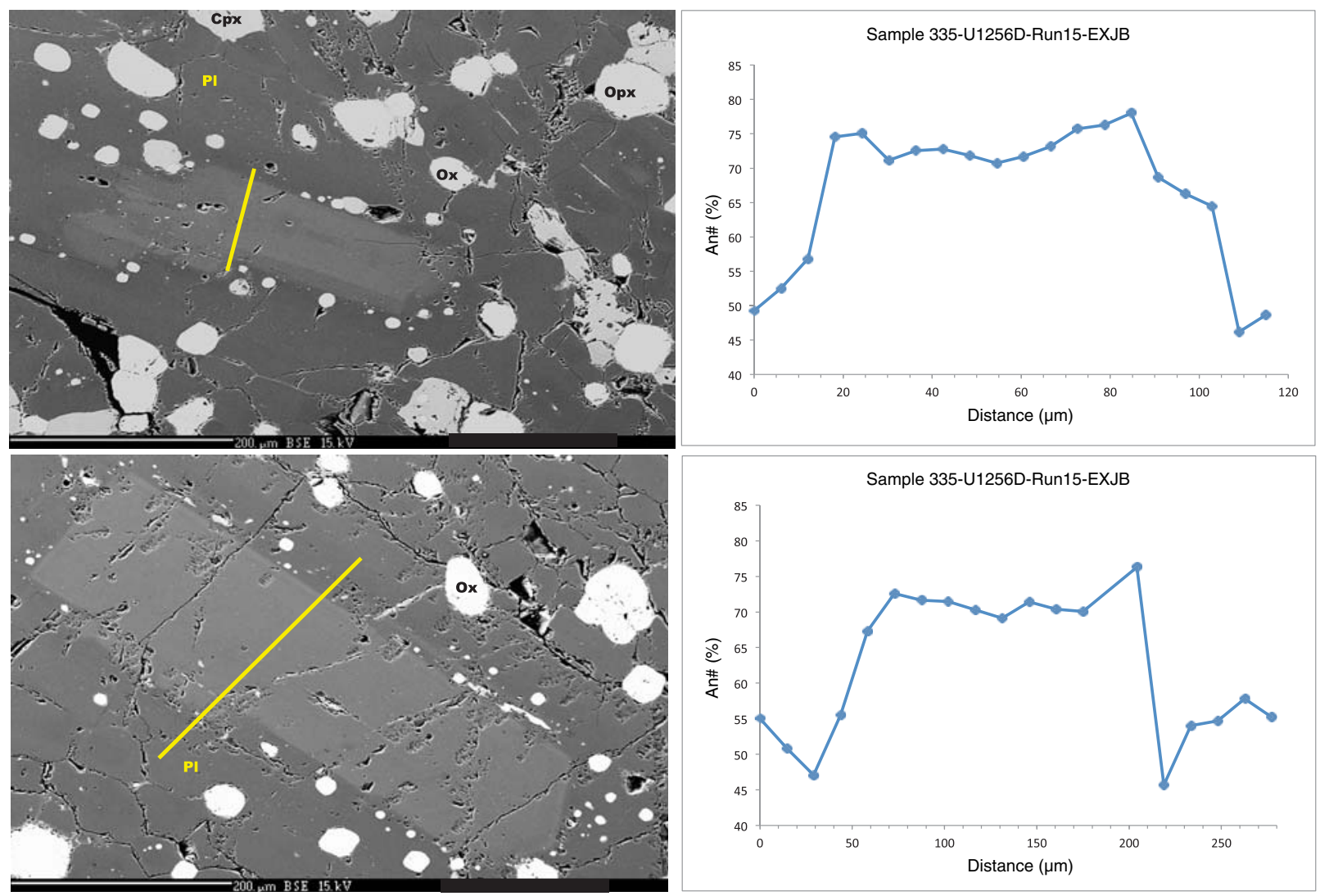
Figure F4. Backscattered electron (BSE) images of two relict plagioclase phenocrysts and related electron microprobe profiles for anorthite (An) content in a granoblastic hornfels recovered during Expedition 335 (Sample 335-U1256D-Run19-RCJB-D). Yellow lines = position of profiles. $\mathrm{Pl}=$ plagioclase, $\mathrm{Cpx}=$ clinopyroxene, $\mathrm{Opx}=$ orthopyroxene, $\mathrm{Ox}=$ oxide.
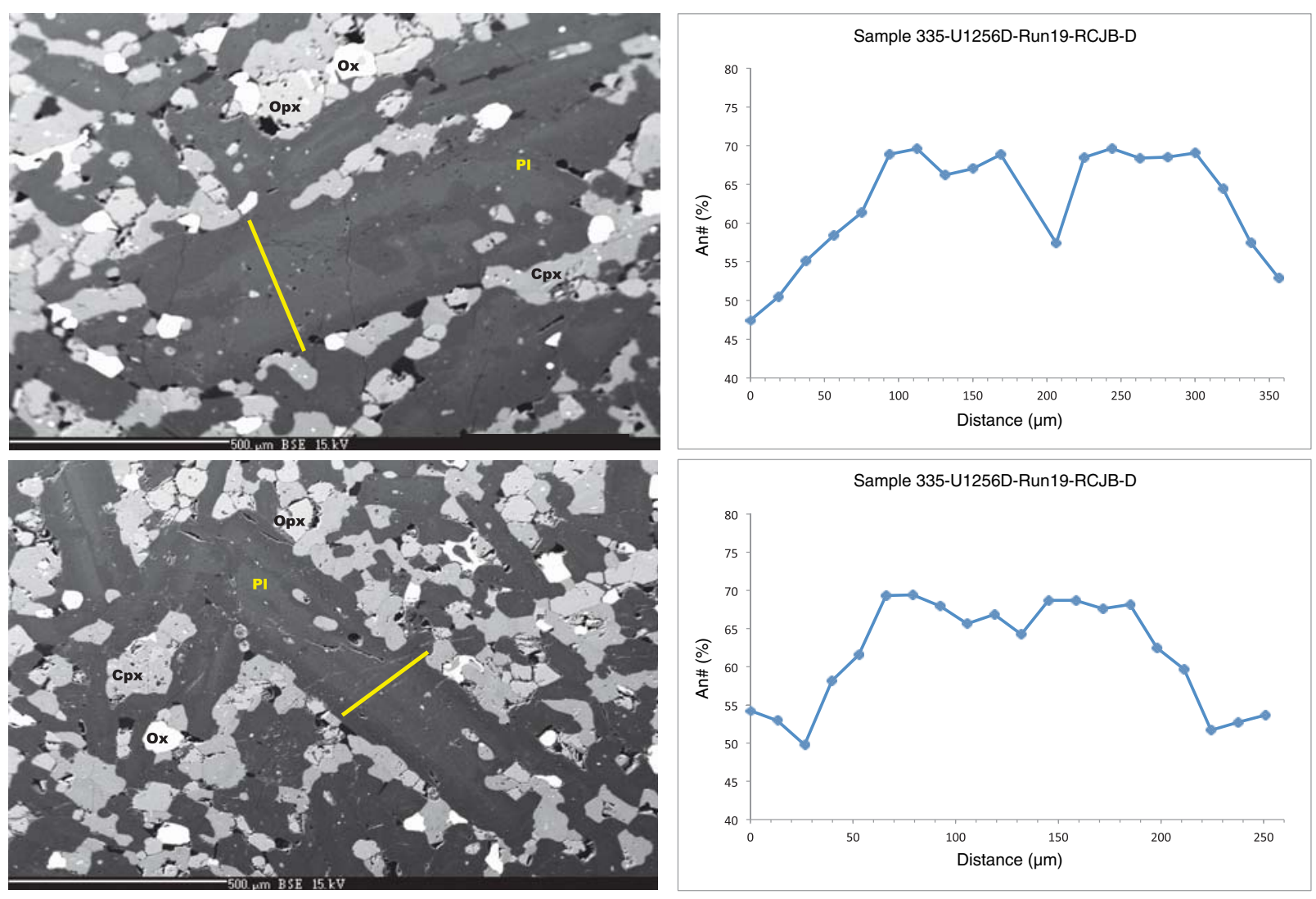
Figure F5. Backscattered electron (BSE) image of a typical "plagioclase ghost core" and related electron microprobe profiles for anorthite (An) content in a granoblastic hornfels recovered during Expedition 335 (Sample 335-U1256D-Run12-RCJB-B). Yellow line = position of profile.
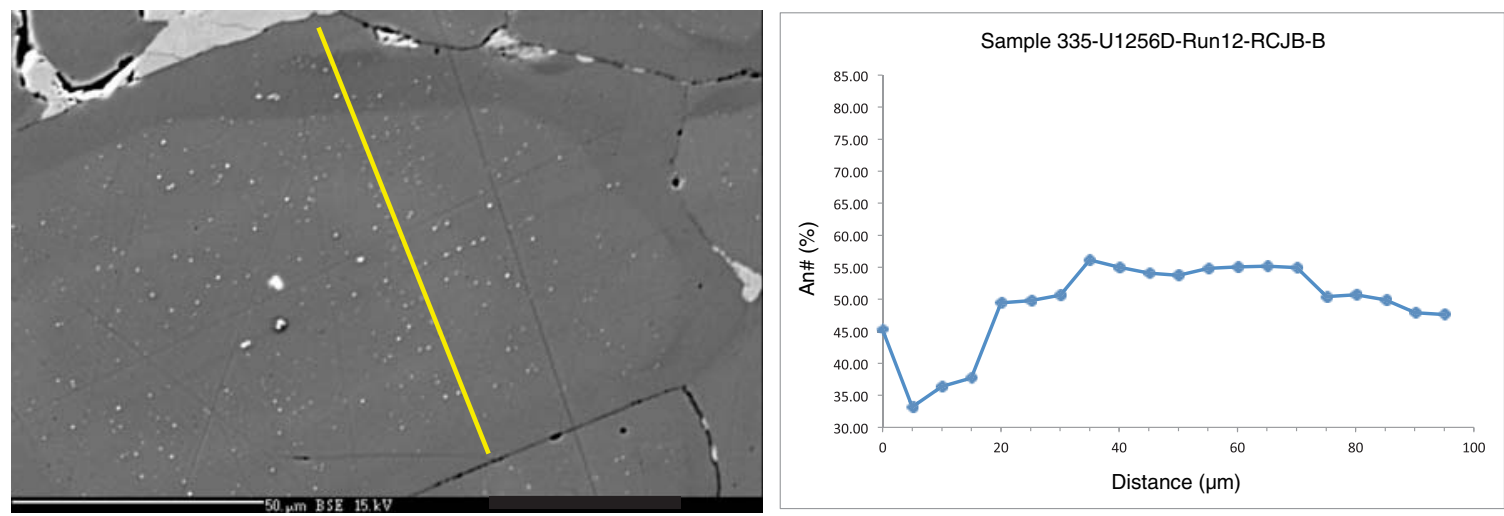
Figure F6. Backscattered electron (BSE) images of pyroxene bands and clusters in granoblastic hornfels recovered during Expedition 335. A. Typical parallel bands consisting of clino- and orthopyroxene (Sample 335U1256D-Run12-RCJB-Q). Analyses of pyroxene in Table T3 show very similar compositions as the matrix orthopyroxene. B. Cluster of pyroxene mainly consisting of orthopyroxene Sample 335-U1256D-Run12-RCJB-S). Compositions of the minerals in the cluster are nearly identical with those of the matrix.
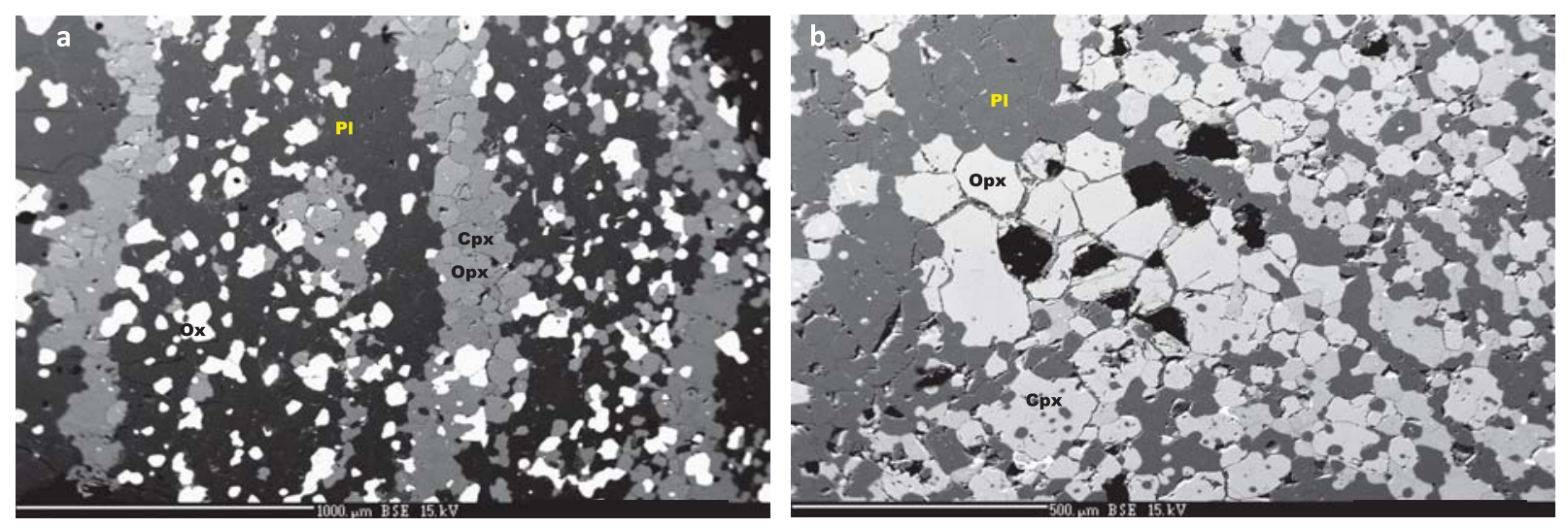
Figure F7. Selected compositional parameters for plagioclase (Plag) and pyroxene from granoblastic hornfels recovered from Hole 1256D. Data points correspond to averages presented in Table T3. Included are also fields for primary clinopyroxene (Cpx) and Plag from fresh basalts from Leg 206 and Expedition 309 published by Dziony et al. (2008), as well as compositions from Plag, Cpx, and orthopyroxene (Opx) from granoblastic hornfels drilled during Expedition 312 published by Koepke et al. (2008). All data correspond to averages of core compositions. A. FeO vs. anorthite (An) content in Plag for both relict phenocrysts and matrix grains (only core analyses). Data for matrix Plag from Sample 335-1256D-235R-1W-19 were excluded due to relics of primary An-rich Plag (see text for detail). Note that the phenocryst compositions are distinctly higher in An content compared to the compositions of the matrix Plag overlapping with those compositions characteristic for primary Plag in fresh basalts and dikes recovered from the upper part of the Hole 1256D drill core. B. Pyroxene quadrilateral enstatite (En), ferrosilite (Fs), and wollastonite (Wo). Only core analyses were used. Note the good correspondence with pyroxenes from granoblastic hornfels drilled during Expedition 312 and the marked difference in compositions between Cpx of the granoblastic hornfels and that of the fresh basalts and dikes drilled in the upper part of the hole. $\mathrm{C}$. $\mathrm{TiO}_{2}$ vs. $\mathrm{Al}_{2} \mathrm{O}_{3}$ in $\mathrm{Cpx}$. Note the good correspondence between core, rim, and other analyses (miscellaneous [misc] in veins, clusters, and bands and as inclusions in other minerals) implying that a high grade of global chemical equilibrium in these samples has been achieved. $\mathrm{D}$. $\mathrm{TiO}_{2}$ vs. $\mathrm{Al}_{2} \mathrm{O}_{3}$ in Opx. Note the good correspondence between core, rim, and other analyses (miscellaneous [misc] in veins, clusters, and bands) varying only in a small interval.

A
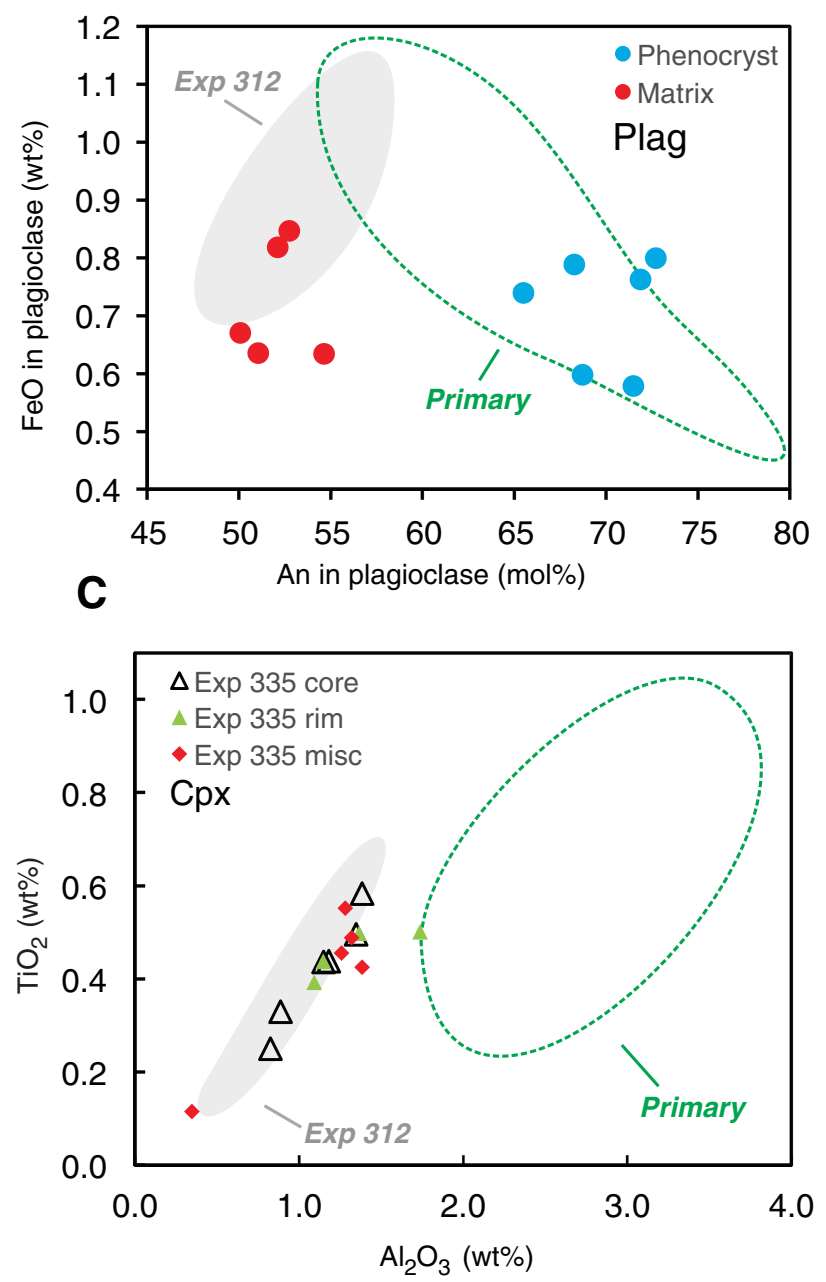

B
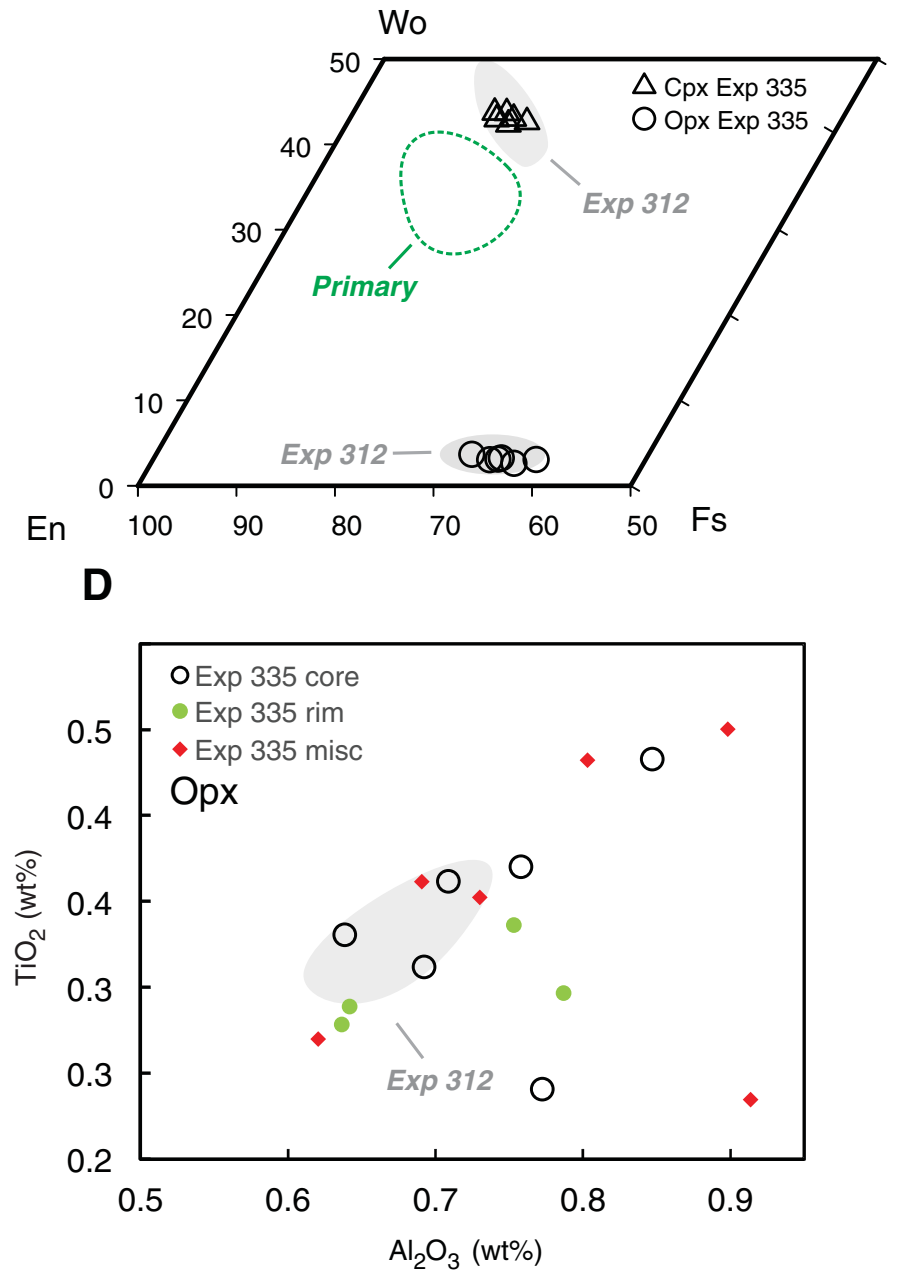
Table T1. Overview of analyzed samples in this study, Hole 1256D.

\begin{tabular}{|c|c|c|c|c|c|c|c|c|}
\hline Sample & Rock & $\begin{array}{l}\text { Top } \\
\text { (mbsf) }\end{array}$ & $\begin{array}{l}\text { Bottom } \\
\text { (mbsf) }\end{array}$ & Comments & $\begin{array}{c}\text { Length } \\
(\mathrm{cm})\end{array}$ & $\begin{array}{l}\text { Width } \\
(\mathrm{cm})\end{array}$ & $\begin{array}{l}\text { Height } \\
(\mathrm{cm})\end{array}$ & $\begin{array}{l}\text { Weight } \\
\text { (g) }\end{array}$ \\
\hline \multicolumn{9}{|l|}{$335-$} \\
\hline 1256D-235R-1W-19 & & 1520.39 & 1520.43 & Drilled sample & 4 & 1 & 1 & 12 \\
\hline U1256D-Run12-RCJB-B & B & 1516 & 1518 & Cobble (granoblastic) & 15.5 & 11 & 8.5 & 3175.1 \\
\hline U1256D-Run12-RCJB-Q & Q & 1516 & 1518 & Cobble (granoblastic) & 6.5 & 3.5 & 2.5 & 98.5 \\
\hline U1256D-Run12-RCJB-S & $S$ & 1516 & 1518 & Cobble (granoblastic) & 7 & 6.5 & 4.5 & 401.4 \\
\hline U1256D-Run15-EXJB & & 1518 & 1520 & Centimeter-sized cuttings & 1 & 1 & 1 & 4 \\
\hline U1256D-Run19-RCJB-D & $\mathrm{D}$ & 1518 & 1521 & Cobble (granoblastic) & 13.5 & 10.5 & 6 & 1134 \\
\hline
\end{tabular}

$\mathrm{RCJB}=$ reverse circulation junk baskets, EXJB = external junk basket. For details on sampling, see Teagle, Ildefonse, Blum, and the Expedition 335 Scientists, 2012. 
Table T2. Petrographic features of analyzed granoblastic dikes, Expedition 335.

\begin{tabular}{|c|c|c|c|c|c|}
\hline Sample & Grain size $^{*}$ & Minerals present & Minerals analyzed & Petrographic features, comments & $\begin{array}{c}\text { Shipboard } \\
\text { TS\# }^{\dagger}\end{array}$ \\
\hline \multicolumn{6}{|l|}{$335-$} \\
\hline 1256D-235R-1W-19 & Microcrystalline & $\begin{array}{l}\text { Plagioclase, } \\
\text { clinopyroxene, } \\
\text { orthopyroxene, Fe-Ti } \\
\text { oxides, amphibole }\end{array}$ & $\begin{array}{l}\text { Plagioclase phenocrysts (core, rim), plagioclase matrix (core, rim), } \\
\text { clinopyroxene matrix (core, rim), orthopyroxene matrix (core, } \\
\text { rim), amphibole, magnetite matrix, ilmenite matrix, titanite }\end{array}$ & $\begin{array}{l}\text { Presence of plagioclase phenocrysts; tiny oxide inclusions in } \\
\text { pyroxenes; secondary amphibole overgrowth on } \\
\text { clinopyroxene; secondary titanite overgrowth on ilmenite }\end{array}$ & \\
\hline $\begin{array}{l}\text { U1256D-Run12- } \\
\text { RCJB-B }\end{array}$ & Cryptocrystalline & $\begin{array}{l}\text { Plagioclase, } \\
\text { clinopyroxene, } \\
\text { orthopyroxene, Fe-Ti } \\
\text { oxides, amphibole }\end{array}$ & $\begin{array}{l}\text { Plagioclase phenocrysts (core, rim), plagioclase ghost (core, rim), } \\
\text { plagioclase matrix (core, rim), clinopyroxene matrix, } \\
\text { clinopyroxene inclusions in plagioclase, clinopyroxene in vein-like } \\
\text { structure, clinopyroxene cluster, orthopyroxene matrix, } \\
\text { orthopyroxene in vein-like structure, amphibole veins, amphibole } \\
\text { cluster, amphibole overgrowth, magnetite matrix, ilmenite matrix }\end{array}$ & $\begin{array}{l}\text { Clinopyroxene-orthopyroxene assemblages arranged in } \\
\text { vein-like structures and clusters; presence of plagioclase } \\
\text { phenocrysts; secondary amphibole in veins, clusters, and } \\
\text { as overgrowth on clinopyroxene; sample contains } \\
\text { magmatic veins } s^{\ddagger}\end{array}$ & 21 \\
\hline $\begin{array}{l}\text { U1256D-Run12- } \\
\text { RCJB-Q }\end{array}$ & $\begin{array}{l}\text { Microcrystalline to } \\
\text { fine grained }\end{array}$ & $\begin{array}{l}\text { Plagioclase, } \\
\text { clinopyroxene, } \\
\text { orthopyroxene, Fe-Ti } \\
\text { oxides, amphibole }\end{array}$ & $\begin{array}{l}\text { Plagioclase matrix (core, rim), clinopyroxene matrix (core, rim), } \\
\text { clinopyroxene in band-like structure, orthopyroxene matrix (core, } \\
\text { rim), orthopyroxene in band-like structure, amphibole inclusions } \\
\text { in orthopyroxene, magnetite inclusions in orthopyroxene, } \\
\text { magnetite matrix, ilmenite matrix }\end{array}$ & $\begin{array}{l}\text { Very heterogeneous rock with marked foliation and banding } \\
\text { due to parallel continuous or discontinuous bands } \\
\text { dominated by orthopyroxene and clinopyroxene } \ddagger\end{array}$ & 25 \\
\hline $\begin{array}{l}\text { U1256D-Run12- } \\
\text { RCJB-S }\end{array}$ & $\begin{array}{l}\text { Microcrystalline to } \\
\text { fine grained }\end{array}$ & $\begin{array}{l}\text { Plagioclase, } \\
\text { clinopyroxene, } \\
\text { orthopyroxene, Fe-Ti } \\
\text { oxides }\end{array}$ & $\begin{array}{l}\text { Plagioclase phenocrysts (core, rim), plagioclase matrix, plagioclase } \\
\text { in vein-like structure, clinopyroxene matrix (core, rim), } \\
\text { clinopyroxene matrix (core, rim), orthopyroxene in vein-like } \\
\text { structure, magnetite matrix, magnetite inclusions in } \\
\text { orthopyroxene, ilmenite matrix, ilmenite inclusions in } \\
\text { orthopyroxene }\end{array}$ & $\begin{array}{l}\text { Sample contains two domains of different grain sizes, } \\
\text { interpreted as former dike/dike contact; presence of } \\
\text { plagioclase phenocryst }\end{array}$ & 26 \\
\hline U1256D-Run15-EXJB & Microcrystalline & $\begin{array}{l}\text { Plagioclase, } \\
\text { clinopyroxene, } \\
\text { orthopyroxene, Fe-Ti } \\
\text { oxides }\end{array}$ & $\begin{array}{l}\text { Plagioclase phenocrysts (core, rim), plagioclase ghost (core, rim), } \\
\text { plagioclase matrix, clinopyroxene matrix, orthopyroxene matrix, } \\
\text { orthopyroxene cluster, magnetite cluster, magnetite matrix, } \\
\text { ilmenite matrix }\end{array}$ & $\begin{array}{l}\text { Very heterogeneous rock with foliation and bands where } \\
\text { orthopyroxene and plagioclase is enriched; patchy clusters } \\
\text { of orthopyroxene; many plagioclases with ghost cores; } \\
\text { presence of plagioclase phenocrysts; high modal amount } \\
\text { of Fe-Ti oxide with clusters of oxide and countless oxide } \\
\text { inclusions in plagioclase and pyroxene }\end{array}$ & 35 \\
\hline $\begin{array}{l}\text { U1256D-Run19- } \\
\text { RCJB-D }\end{array}$ & $\begin{array}{l}\text { Cryptocrystalline to } \\
\text { microcrystalline }\end{array}$ & $\begin{array}{l}\text { Plagioclase, } \\
\text { clinopyroxene, } \\
\text { orthopyroxene, Fe-Ti } \\
\text { oxides, amphibole }\end{array}$ & $\begin{array}{l}\text { Plagioclase phenocrysts (core, rim), clinopyroxene matrix (core, } \\
\text { rim), orthopyroxene matrix (core, rim), amphibole, magnetite } \\
\text { matrix, ilmenite matrix }\end{array}$ & $\begin{array}{l}\text { Presence of plagioclase phenocrysts; presence of vein-like } \\
\text { structures of mainly orthopyroxene; secondary amphibole } \\
\text { overgrowth on clinopyroxene and in veins }\end{array}$ & \\
\hline
\end{tabular}

${ }^{*}=$ grain sizes are related to the granoblastic matrix and were defined according to Teagle, Ildefonse, Blum, and the Expedition 335 Scientists, 2012 : cryptocrystalline $=<0.1$ mm, microcrys-

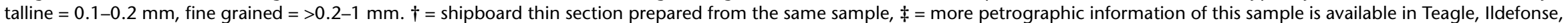
Blum, and the Expedition 335 Scientists, 2012. 
Table T3. Average mineral compositions of selected granoblastic dikes recovered from Hole 1256D during Expedition 335. (Continued on next three pages.)

\begin{tabular}{|c|c|c|c|c|c|c|c|c|c|c|c|c|c|c|c|c|c|c|c|}
\hline Phase & Analysis & Qualifier & $N$ & $\mathrm{SiO}_{2}$ & $\mathrm{TiO}_{2}$ & $\mathrm{Al}_{2} \mathrm{O}_{3}$ & $\mathrm{Cr}_{2} \mathrm{O}_{3}$ & $\mathrm{FeO}$ & $\mathrm{MnO}$ & $\mathrm{MgO}$ & $\mathrm{CaO}$ & $\mathrm{Na}_{2} \mathrm{O}$ & $\mathrm{K}_{2} \mathrm{O}$ & $\mathrm{V}_{2} \mathrm{O}_{3}$ & $\mathrm{~F}$ & $\mathrm{Cl}$ & Total & Mg\# & An\# \\
\hline \multicolumn{20}{|c|}{ Sample 335-1256D-235R-1W-19 } \\
\hline \multirow[t]{2}{*}{ Plag } & $\operatorname{Rim}$ & Pheno & 3 & 52.96 & - & 29.77 & - & 0.56 & - & - & 12.91 & 4.32 & 0.07 & & & & 100.59 & & 62.07 \\
\hline & & & & 0.54 & - & 0.16 & - & 0.08 & - & - & 0.42 & 0.32 & 0.00 & & & & 0.36 & & 2.38 \\
\hline \multirow[t]{2}{*}{ Plag } & Core & Pheno & 12 & 50.43 & - & 31.30 & - & 0.58 & - & - & 14.72 & 3.22 & 0.04 & & & & 100.29 & & 71.47 \\
\hline & & & & 0.47 & - & 0.36 & - & 0.07 & - & - & 0.39 & 0.17 & 0.01 & & & & 0.39 & & 1.55 \\
\hline \multirow[t]{2}{*}{ Plag } & Rim & Matrix & 20 & 54.43 & 0.06 & 28.75 & - & 0.56 & - & - & 11.76 & 4.98 & 0.09 & & & & 100.59 & & 56.35 \\
\hline & & & & 0.60 & 0.01 & 0.53 & - & 0.08 & - & - & 0.47 & 0.26 & 0.04 & & & & 0.36 & & 2.26 \\
\hline \multirow[t]{2}{*}{ Plag } & Core & Matrix & 12 & 51.25 & 0.06 & 30.76 & - & 0.61 & - & - & 14.18 & 3.57 & 0.05 & & & & 100.42 & & 68.51 \\
\hline & & & & 0.96 & 0.01 & 0.72 & - & 0.17 & - & - & 0.85 & 0.44 & 0.02 & & & & 0.40 & & 3.99 \\
\hline \multirow{2}{*}{ Cpx } & Rim & Matrix & 22 & 52.43 & 0.50 & 1.36 & - & 9.31 & 0.25 & 14.78 & 21.89 & 0.27 & - & & & & 100.81 & 73.89 & \\
\hline & & & & 0.44 & 0.14 & 0.25 & - & 0.47 & 0.05 & 0.31 & 0.55 & 0.04 & - & & & & 0.58 & 1.06 & \\
\hline \multirow[t]{2}{*}{ Cpx } & Core & Matrix & 30 & 52.65 & 0.50 & 1.35 & - & 9.57 & 0.25 & 14.37 & 21.45 & 0.26 & - & & & & 100.38 & 72.82 & \\
\hline & & & & 0.50 & 0.18 & 0.32 & - & 0.67 & 0.04 & 0.30 & 0.77 & 0.07 & - & & & & 0.45 & 1.36 & \\
\hline \multirow[t]{2}{*}{ Opx } & $\operatorname{Rim}$ & Matrix & 21 & 53.02 & 0.34 & 0.75 & - & 21.72 & 0.45 & 23.04 & 1.41 & - & - & & & & 100.78 & 65.42 & \\
\hline & & & & 0.27 & 0.05 & 0.07 & - & 0.41 & 0.07 & 0.32 & 0.20 & - & - & & & & 0.53 & 0.56 & \\
\hline \multirow[t]{2}{*}{ Opx } & Core & Matrix & 30 & 53.26 & 0.37 & 0.76 & - & 21.84 & 0.47 & 22.13 & 1.53 & - & - & & & & 100.36 & 64.37 & \\
\hline & & & & 0.29 & 0.06 & 0.10 & - & 0.41 & 0.05 & 0.21 & 0.26 & - & - & & & & 0.51 & 0.53 & \\
\hline \multirow[t]{2}{*}{ Amph } & & Overgrowth & 20 & 50.85 & 0.50 & 2.61 & - & 12.50 & 0.20 & 15.45 & 12.79 & 0.56 & 0.06 & & - & 0.15 & 95.63 & 68.80 & \\
\hline & & & & 0.97 & 0.31 & 1.03 & - & 2.74 & 0.04 & 1.76 & 3.74 & 0.24 & 0.02 & & - & 0.07 & 1.35 & 6.57 & \\
\hline \multirow[t]{2}{*}{ Mt } & & Matrix & 23 & 2.27 & 7.10 & 1.45 & 0.97 & 81.64 & 0.27 & 1.28 & 0.56 & 0.17 & - & & & & 93.39 & & \\
\hline & & & & 2.30 & 8.93 & 0.29 & 0.19 & 8.59 & 0.14 & 1.06 & 0.65 & 0.08 & - & & & & 2.02 & & \\
\hline \multirow{2}{*}{$\mathrm{Ilm}$} & & Matrix & 11 & 0.97 & 49.97 & - & - & 48.32 & 1.47 & 0.33 & 0.31 & - & - & & & & 100.46 & & \\
\hline & & & & 1.20 & 2.43 & - & - & 2.00 & 0.44 & 0.62 & 0.44 & - & - & & & & 0.61 & & \\
\hline \multirow[t]{2}{*}{ Tit } & & Overgrowth & 4 & 30.77 & 36.82 & 2.50 & - & 1.57 & - & - & 28.38 & - & - & & & & 100.05 & & \\
\hline & & & & 0.07 & 0.79 & 0.29 & - & 0.51 & - & - & 0.25 & - & - & & & & 0.43 & & \\
\hline \multicolumn{20}{|c|}{ Sample 335-U1256D-Run12-RCJB-B } \\
\hline Plag & $\operatorname{Rim}$ & Pheno 1 & 6 & 55.16 & 0.07 & 27.92 & - & 0.56 & - & - & 10.61 & 5.55 & 0.05 & & & & 99.92 & & 51.19 \\
\hline & & & & 0.57 & 0.02 & 0.43 & - & 0.15 & - & - & 0.52 & 0.21 & 0.01 & & & & 0.33 & & 2.14 \\
\hline Plag & Core & Pheno 1 & 13 & 51.34 & 0.05 & 30.23 & - & 0.74 & - & - & 13.50 & 3.92 & 0.02 & & & & 99.78 & & 65.49 \\
\hline & & & & 0.32 & 0.01 & 0.20 & - & 0.15 & - & - & 0.29 & 0.13 & 0.01 & & & & 0.29 & & 1.14 \\
\hline Plag & Rim & Pheno 2 & 7 & 54.89 & 0.07 & 28.10 & - & 0.73 & - & - & 10.87 & 5.39 & 0.05 & & & & 100.10 & & 52.56 \\
\hline & & & & 0.57 & 0.02 & 0.24 & - & 0.24 & - & - & 0.39 & 0.22 & 0.01 & & & & 0.39 & & 1.87 \\
\hline Plag & Core & Pheno 2 & 12 & 49.92 & 0.04 & 31.15 & - & 0.76 & - & - & 14.69 & 3.17 & 0.01 & & & & 99.71 & & 71.88 \\
\hline & & & & 0.47 & 0.00 & 0.32 & - & 0.16 & - & - & 0.36 & 0.16 & 0.01 & & & & 0.38 & & 1.42 \\
\hline Plag & Rim & Ghost & & 55.10 & 0.07 & 27.81 & & 0.67 & & & 10.54 & 5.57 & 0.06 & & & & 99.81 & & 50.90 \\
\hline & & & & 0.70 & 0.02 & 0.31 & - & 0.12 & - & - & 0.49 & 0.40 & 0.00 & & & & 0.50 & & 2.88 \\
\hline Plag & Core & Ghost & & 54.80 & 0.08 & 28.01 & & 1.14 & & & 10.78 & 5.41 & 0.05 & & & & 100.26 & & 52.30 \\
\hline & & & & 0.56 & 0.01 & 0.17 & - & 0.64 & - & - & 0.29 & 0.14 & 0.01 & & & & 0.29 & & 1.18 \\
\hline Plag & Rim & Matrix & 21 & 56.12 & 0.06 & 27.16 & - & 0.64 & - & - & 9.80 & 5.96 & 0.06 & & & & 99.87 & & 47.46 \\
\hline & & & & 0.73 & 0.01 & 0.98 & - & 0.54 & - & - & 0.48 & 0.28 & 0.01 & & & & 0.40 & & 2.19 \\
\hline Plag & Core & Matrix & 29 & 54.83 & 0.08 & 27.83 & - & 0.85 & - & - & 10.78 & 5.31 & 0.05 & & & & 99.82 & & 52.75 \\
\hline & & & & 0.65 & 0.02 & 1.00 & - & 0.62 & - & - & 0.47 & 0.33 & 0.01 & & & & 0.46 & & 1.94 \\
\hline Cpx & & Matrix & 9 & 52.82 & 0.33 & 0.89 & - & 9.34 & 0.23 & 15.12 & 21.47 & 0.31 & - & & & & 100.51 & 74.28 & \\
\hline & & & & 0.67 & 0.26 & 0.46 & - & 0.73 & 0.03 & 0.19 & 0.81 & 0.04 & - & & & & 0.32 & 1.55 & \\
\hline Cpx & & Inclusion & 2 & 52.47 & 0.42 & 1.38 & - & 9.74 & 0.23 & 14.94 & 20.47 & 0.34 & - & & & & 99.99 & 73.23 & \\
\hline & & & & 0.66 & 0.25 & 0.23 & - & 0.34 & 0.02 & 0.17 & 0.32 & 0.01 & - & & & & 0.31 & 0.90 & \\
\hline $\mathrm{Cpx}$ & & Vein & 3 & 52.03 & 0.55 & 1.28 & - & 9.60 & 0.26 & 15.07 & 21.08 & 0.31 & - & & & & 100.17 & 73.68 & \\
\hline & & & & 0.63 & 0.15 & 0.21 & - & 0.56 & 0.02 & 0.12 & 0.57 & 0.01 & - & & & & 0.43 & 1.13 & \\
\hline Cpx & & Cluster & 7 & 53.39 & 0.12 & 0.34 & - & 8.28 & 0.25 & 14.64 & 23.13 & 0.21 & - & & & & 100.32 & 75.93 & \\
\hline & & & & 0.32 & 0.09 & 0.21 & - & 0.71 & 0.05 & 0.34 & 0.70 & 0.08 & - & & & & 0.28 & 1.89 & \\
\hline
\end{tabular}




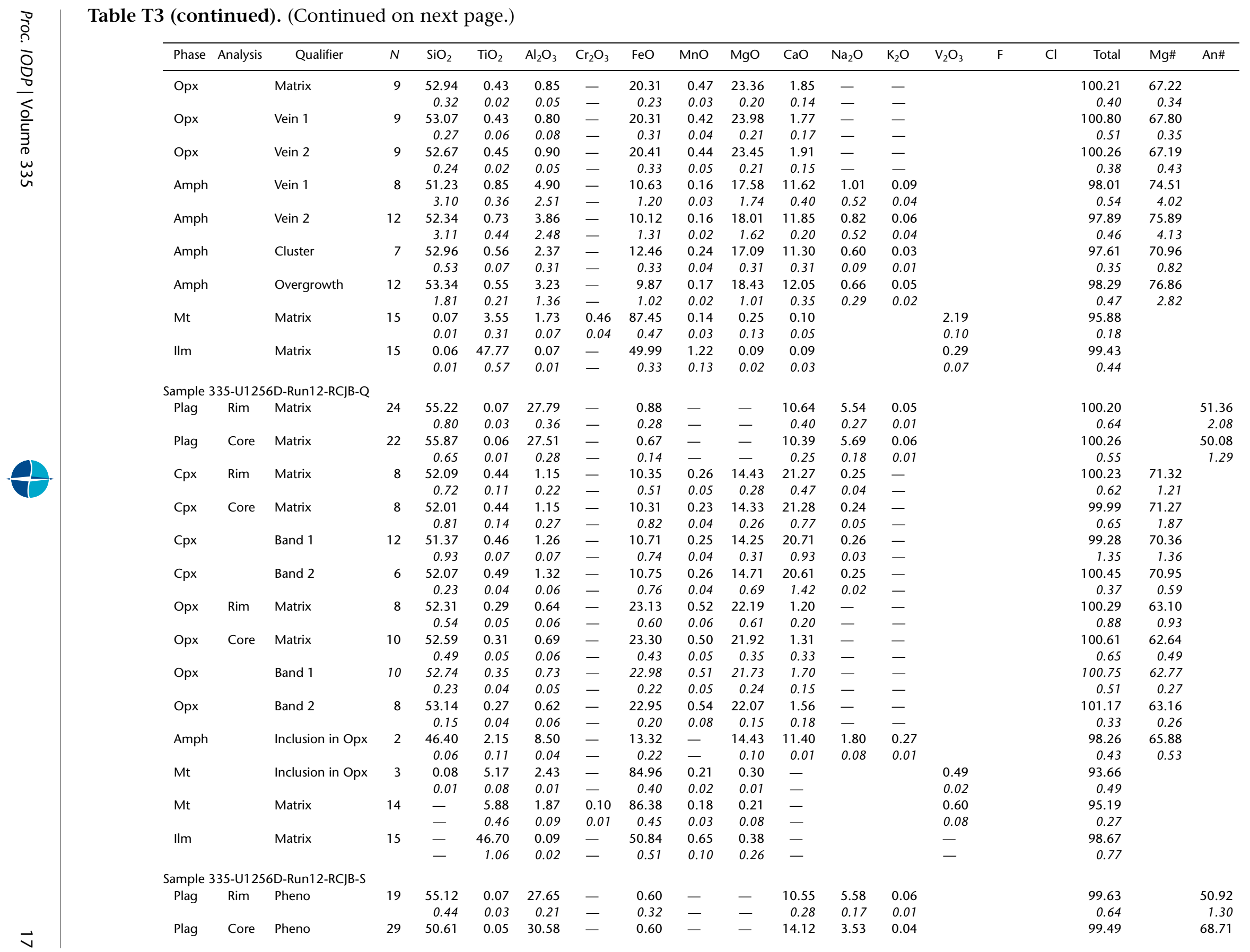

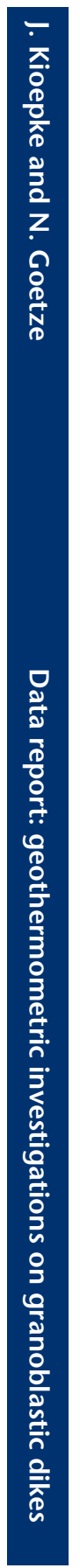


Table T3 (continued). (Continued on next page.)

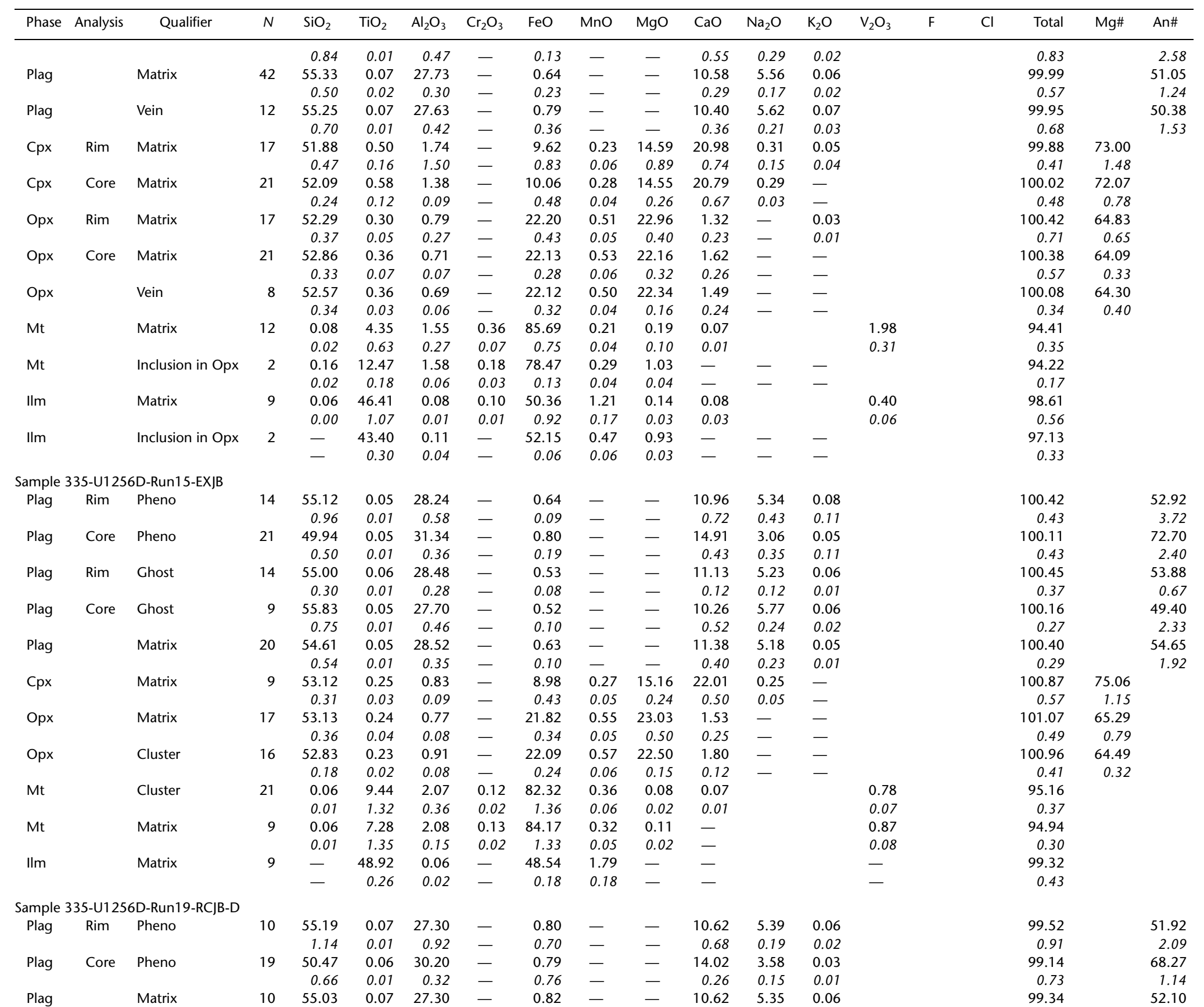


Table T3 (continued).

\begin{tabular}{|c|c|c|c|c|c|c|c|c|c|c|c|c|c|c|c|c|c|c|c|}
\hline Phase & Analysis & Qualifier & $N$ & $\mathrm{SiO}_{2}$ & $\mathrm{TiO}_{2}$ & $\mathrm{Al}_{2} \mathrm{O}_{3}$ & $\mathrm{Cr}_{2} \mathrm{O}_{3}$ & $\mathrm{FeO}$ & $\mathrm{MnO}$ & $\mathrm{MgO}$ & $\mathrm{CaO}$ & $\mathrm{Na}_{2} \mathrm{O}$ & $\mathrm{K}_{2} \mathrm{O}$ & $\mathrm{V}_{2} \mathrm{O}_{3}$ & $\mathrm{~F}$ & $\mathrm{Cl}$ & Total & Mg\# & An\# \\
\hline & & & & 1.16 & 0.01 & 0.92 & - & 0.70 & - & - & 0.68 & 0.23 & 0.02 & & & & 0.79 & & 2.30 \\
\hline \multirow[t]{2}{*}{ Cpx } & $\operatorname{Rim}$ & Matrix & 49 & 52.00 & 0.39 & 1.09 & - & 10.39 & 0.26 & 14.27 & 21.39 & 0.24 & - & & & & 100.05 & 71.02 & \\
\hline & & & & 0.43 & 0.12 & 0.22 & - & 0.55 & 0.04 & 0.25 & 0.56 & 0.04 & - & & & & 0.47 & 1.21 & \\
\hline \multirow[t]{2}{*}{ Cpx } & Core & Matrix & 26 & 52.20 & 0.44 & 1.18 & - & 11.10 & 0.26 & 13.73 & 20.79 & 0.23 & - & & & & 99.93 & 68.86 & \\
\hline & & & & 0.49 & 0.10 & 0.18 & - & 0.97 & 0.06 & 0.24 & 1.25 & 0.04 & - & & & & 0.60 & 1.79 & \\
\hline \multirow{2}{*}{ Opx } & $\operatorname{Rim}$ & Matrix & 48 & 52.20 & 0.28 & 0.64 & - & 24.05 & 0.50 & 21.71 & 1.30 & - & - & & & & 100.71 & 61.68 & \\
\hline & & & & 0.27 & 0.06 & 0.06 & - & 0.39 & 0.07 & 0.41 & 0.19 & - & - & & & & 0.58 & 0.52 & \\
\hline \multirow[t]{2}{*}{ Opx } & Core & Matrix & 33 & 52.46 & 0.33 & 0.64 & - & 24.03 & 0.51 & 20.53 & 1.50 & - & - & & & & 99.99 & 60.37 & \\
\hline & & & & 0.38 & 0.06 & 0.07 & - & 0.29 & 0.06 & 0.33 & 0.30 & - & - & & & & 0.66 & 0.51 & \\
\hline Amph & & Overgrowth & 1 & 51.39 & 0.13 & 3.12 & - & 19.76 & 0.26 & 12.23 & 9.88 & 0.41 & - & & & & 97.21 & 52.47 & \\
\hline \multirow[t]{2}{*}{ Mt } & & Matrix & 13 & - & 4.82 & 1.43 & 0.36 & 86.82 & 0.20 & - & 0.18 & - & - & & & & 93.70 & & \\
\hline & & & & - & 1.23 & 0.16 & 0.07 & 1.06 & 0.06 & - & 0.10 & - & - & & & & 0.79 & & \\
\hline \multirow[t]{2}{*}{$\mathrm{Ilm}$} & & Matrix & 8 & 3.77 & 42.06 & 1.52 & - & 49.65 & 0.82 & - & 1.54 & - & - & & & & 98.82 & & \\
\hline & & & & 3.80 & 2.93 & 1.90 & - & 3.43 & 0.43 & - & 1.17 & - & - & & & & 1.20 & & \\
\hline
\end{tabular}

Phase: Plag = plagioclase, $\mathrm{Cpx}=$ clinopyroxene, Opx = orthopyroxene, $\mathrm{Amph}=$ amphibole, $\mathrm{Mt}=$ magnetite, Ilm = ilmenite, Tit $=$ titanite. Empty cells in Analysis column indicate analysis was

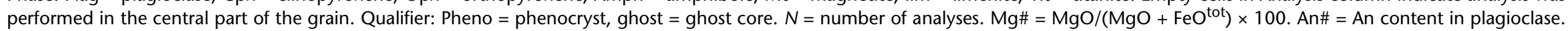
Values in italics are one standard deviation of the average value above. $-=$ below limit of detection, empty cell = not analyzed 
Table T4. Equilibrium temperatures calculated by three different geothermometers, Hole 1256D.

\begin{tabular}{lccc}
\hline \multicolumn{1}{c}{ Sample } & $\begin{array}{c}\text { QUILF } \\
\text { temperature } \\
\left({ }^{\circ} \mathrm{C}\right)\end{array}$ & $\begin{array}{c}\text { Putirka } \\
\text { temperature } \\
\left({ }^{\circ} \mathrm{C}\right)\end{array}$ & $\begin{array}{c}\text { Ti-in-amphibole } \\
\text { temperature }\left({ }^{\circ} \mathrm{C}\right)\end{array}$ \\
\hline 335-1256D-235R-1W-19 & $940 \pm 50$ & 936 & $586^{*}$ \\
335-U1256D-Run12-RCJB-B & $994 \pm 60$ & 929 & $596^{*}-626^{\dagger}$ \\
335-U1256D-Run12-RCJB-Q & $958 \pm 62$ & 981 & $853^{\ddagger}$ \\
335-U1256D-Run12-RCJB-S & $961 \pm 53$ & 967 & \\
335-U1256D-Run15-EXJB & $962 \pm 92$ & 942 & \\
335-U1256D-Run19-RCJB-D & $930 \pm 44$ & 974 & $509^{*}$ \\
\hline
\end{tabular}

${ }^{*}=$ overgrowth, $\dagger=$ average of different veins and clusters, $\ddagger=$ blebs in orthopyroxene. QUILF calculated according to Andersen et al. (1993) based on the two-pyroxene equilibrium. Putirka calculated according to Putirka (2008) based on the two-pyroxene equilibrium. Ti-in-amphibole temperature calculated according to Ernst and Liu (1998). 